\title{
The Influence of Bioproducts on Mycorrhizal Occurrence and Diversity in the Rhizosphere of Strawberry Plants under Controlled Conditions
}

\author{
Lidia Sas Paszt ${ }^{1 *}$, Eligio Malusá1,2, Beata Sumorok ${ }^{1}$, Loredana Canfora ${ }^{2}$, \\ Edyta Derkowska1, Sławomir Głuszek ${ }^{1}$ \\ ${ }^{1}$ Research Institute of Horticulture, Skierniewice, Poland \\ ${ }^{2}$ Consiglio per la Ricerca e Sperimentazione in Agricoltura, Rome, Italy \\ Email: lidia.sas@inhort.pl
}

Received 1 January 2015; accepted 20 January 2015; published 23 January 2015

Copyright (C) 2015 by authors and Scientific Research Publishing Inc.

This work is licensed under the Creative Commons Attribution International License (CC BY).

http://creativecommons.org/licenses/by/4.0/

C) (i) Open Access

\begin{abstract}
The new products obtained from natural resources are an alternative to methods based on traditional mineral fertilizers, which are destructive for soil mycorrhizal communities. Our experiment was carried out to evaluate the effect of organic fertilizers and amendments of very diverse composition on mycorrhizal abundance and diversity, as well as on root growth, in strawberry plants cv. "Honeoye". The plants were grown in rhizoboxes filled with a podsolic soil. The plants were treated with granulated bovine manure, vermicompost extract, humates extract, plant extract, extract from seaweed species reinforced with humic and fulvic acids, a consortium of beneficial soil organisms, a stillage from yeast production and a solution of titanium. Plants treated with products and the microorganisms consortium also received half dose of manure. A standard mineral fertilization (NPK) and an unfertilized control were also included. The bioproducts based on humus-like substances and the yeast stillage had the greatest positive influence on the colonization of roots by arbuscular mycorrhizal fungi (AMF). The different treatments affected the diversity of AMF species present in the rhizospheric soil. All organic products, even though providing a significantly low amount of nutrients, enhanced root growth characteristics in comparison to the mineral fertilization.
\end{abstract}

\section{Keywords}

AMF, Mycorrhizal Frequency, Organic Fertilizers, Root Morphology

\footnotetext{
"Corresponding author.
}

How to cite this paper: Paszt, L.S., Malusá, E., Sumorok, B., Canfora, L., Derkowska, E. and Głuszek, S. (2015) The Influence of Bioproducts on Mycorrhizal Occurrence and Diversity in the Rhizosphere of Strawberry Plants under Controlled Conditions. Advances in Microbiology, 5, 40-53. http://dx.doi.org/10.4236/aim.2015.51005 


\section{Introduction}

The utilisation of products of organic origin in agriculture, especially fertilizers and soil amendments, has increased in the last years. The search for new resources of organic fertilizers for a modern environment-friendly agriculture, including organic farming, derives from the limited availability of traditional ones, such as manure. There is also the need for limitation of use of synthetic fertilizers, which have been found to induce disturbance to soil characteristics (acidification, degradation of soil biota) [1] [2]. Environment-friendly sources for the production of organic fertilizers include plant or animal tissues extracts, humic products, some food industry byproducts, microbial and fungal inocula [3]. These preparations are generally classified into three major groups on the basis of their original matrix: humic substances, marine bioactive substances, and amino acid containing products [4]. They contain macro and micro nutrients, low molecular weight molecules and diverse biologically active substances (e.g. plant hormone-like substances, enzymes, vitamins, etc.) that strongly interact with the physiology of the plant and stimulate plant growth and yielding, also increasing plant resistance to environmental and biotic stresses [5]-[7]. These products have also positive effects on soil biota, including arbuscular mycorrhizal fungi [8] [9]. Enrichment of fertilizers with bacterial and fungal strains could enhance their effectiveness in plant production [10].

Arbuscular mycorrhizal fungi belonging to the phylum Glomeromycota are the most widespread group of symbiotic fungi, with $80 \%$ of land plants forming AMF symbiosis [11]. The fungi obtain and utilize the products of photosynthesis from their host, and deliver several soil nutrients to the plant root system, particularly phosphorus [12]. Strawberry is an economically important fruit crop species with very high demand of phosphorus and symbiosis with AMF is considered a very important mechanism of nutrients uptake both in intensive and low input crop systems [13]-[15]. Several authors found a certain degree of strawberry root colonisation by indigenous AM fungi [16]-[18] and their beneficial effects on plant growth or yielding were described by several publications [19]-[21]. However, in some cases negative effects of mycorrhization were also reported [22] [23].

AMF can play an important role in compensating for reduced use of chemical fertilisers and improving soil nutrients utilization in organic agriculture or other low-input agricultural systems [12] [24]. However, little is known about the influence of organic fertilizers deriving from new sources and matrixes on the root colonization of strawberry plants. We have thus evaluated the effect of the application of different foliar and soil organic fertilizers and amendments on mycorrhizal colonization, diversity and abundance in the rhizosphere of strawberry plants "Honeoye" and their relation to root growth.

\section{Material and Methods}

\subsection{Experimental Set-Up}

The experiment was carried out in a greenhouse over a 5-month period with the use of frigo-plants of the strawberry cultivar "Honeoye". The plants were planted in rhizoboxes $(37 \times 1.8 \times 20 \mathrm{~cm})$, filled with $1.85 \mathrm{~kg}$ of a podsolic soil collected from an uncultivated field of an experimental organic orchard of the RIH. Five rhizoboxes, each containing two plants, were used as replications for each treatment. The plants were subjected to the following growing conditions: photoperiod $16 / 8 \mathrm{~h}$ (day/night), light intensity $70 \mu \mathrm{M} \cdot \mathrm{m}^{-2} \mathrm{~s}^{-1}$, temperature $25 / 20^{\circ} \mathrm{C}$ and air humidity approx. 50\% [14]. The levels of nutrient elements in the soil were: organic matter $1.5 \%$, P 51 $\mathrm{mg} / \mathrm{kg}, \mathrm{K} 158 \mathrm{mg} / \mathrm{kg}$, pH 5.5 .

The following experimental treatments were applied:

1) Control (no-treatment).

Soil fertilizers:

2) Mineral fertilizer (NPK): $1.02 \mathrm{~g} \mathrm{NH}_{4} \mathrm{NO}_{3} ; 1.9 \mathrm{~g}$ triple superphosphate and $1.16 \mathrm{~g} \mathrm{~K}_{2} \mathrm{SO}_{4}$ per rhizobox.

3) Dry granulated bovine manure soil fertilization (Manure) (Doktor O'grodnik) - 1 g per rhizobox.

4) A mixture of AM fungi: Glomus species, Trichoderma viride and rhizosphere bacteria species (Bacillus subtilis, Pseudomonas fluorescens, Streptomyces spp.) (Micosat) (CCS Aosta s.r.1.) - 10 g per rhizobox.

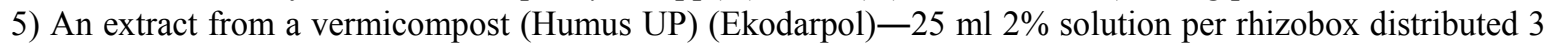
times.

6) A soil improver with humates (Humus Active) (Ekodarpol) - $20 \mathrm{ml}$ 2\% solution of Humus Active and $5 \mathrm{ml}$ $1 \%$ solution of Aktywit PM per rhizobox distributed 3 times.

Foliar fertilizers: 
7) A seaweeds extract reinforced with humic and fulvic acids (BF Quality) (Agrobio Products B.V.) - $25 \mathrm{ml}$ $0.5 \%$ solution sprayed to the leaves three times $+0.5 \mathrm{~g}$ manure to the soil per rhizobox.

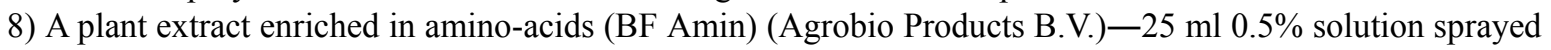
to the leaves three times $+0.5 \mathrm{~g}$ manure to the soil per rhizobox.

9) Titanium (Ti) $0.8 \%$ (Tytanit) (Intermag) $-25 \mathrm{ml} 0.05 \%$ solution sprayed to the leaves three times $+1 \mathrm{~g}$ manure to the soil per rhizobox.

10) A stillage from bakery yeasts production (Vinassa) (Lallemand Polska) $-25 \mathrm{ml} 0.5 \%$ solution sprayed to the leaves three times $+0.5 \mathrm{~g}$ manure to the soil per rhizobox. The amount of the nutrient macroelements provided with each treatment is presented in Table 1 .

\subsection{Determination of Mycorrhizal Frequency}

In order to asses mycorrhizal frequency, strawberry roots were collected at the end of the growing period (five months after inoculation) and cold-stained using the Phillips and Hayman method [25] as modified by Turnau et al. [26]. In particular, first phase-bleaching with $10 \% \mathrm{KOH}$ were carried out for 24 hours. Next phase-acidification with 5\% lactic acid were also carried out for 24 hours. Staining was performed with $0.01 \%$ aniline blue per 24 hours. After staining roots were rinsed with tap water [27].

The microscopic analysis of the roots was carried out according to Trouvelot's method [28]. Thirty 1-cm-long root segments were selected randomly from each of the stained samples. The segments were examined under a Nikon Eclipse E200 microscope. The mycorrhizal frequency (F\%) and mycorrhizal intensity (both relative$\mathrm{M} \%$, and absolute $-\mathrm{m} \%$ ) were assessed in each root segment. The mycorrhizal parameters were calculated using the Mycocalc software (http://www2.dijon.inra.fr/mychintec/Mycocalc-prg/MYCOCALC.EXE).

For each experimental treatment three replicates were analyzed, constituting in total 90 root segments.

\subsection{AMF Spores Counting and Identification}

In order to identify the species of arbuscular mycorrhizal fungi present in the rhizospheric soil of strawberries, trap cultures were set up with narrowleaf plantain (Plantago lanceolata L.). The plants were planted in 0.51 pots (3 repetitions per treatment) filled with a mixture of strawberry rhizosphere soil and autoclaved sand, at a ratio of $1: 1 \mathrm{v} / \mathrm{v}$ [29]. The pots were placed in SunBags (Sigma) and maintained at an air humidity of approx. $70 \%$ and at a soil humidity of about $40 \%$ of the soil water holding capacity, and watered weekly with deionised water to maintain soil moisture. The pots were placed in a glasshouse in a randomised design. Glasshouse temperature was maintained under a $25 / 20^{\circ} \mathrm{C}$ day/night regime. After a six-month growing period $200 \mathrm{~g}$ samples of the pot substrate were taken from the trap cultures combinations, and spores were isolated by wet sieving and centrifuging in a sucrose gradient (at 20\% and then at 60\%) [30]. The isolated spores were used to prepare microscopic specimens which were assessed for identification purposes considering their size, shape, colour, and

Table 1. Amounts of mineral elements applied to the strawberry plants "Honeoye" in rhizoboxes with the different treatments, expressed as $\mathrm{kg} \cdot \mathrm{ha}^{-1}$.

\begin{tabular}{cccc}
\hline Treatments & N & P & K \\
\hline Control & 0.0 & 0.0 & 0.0 \\
NPK & 70 & 26 & 100 \\
Manure & 45 & 13 & 17 \\
Micosat & 23 & 6.5 & 12 \\
Humus UP & 1 & 0.1 & 0.2 \\
Humus Active & 0.5 & 0.1 & 2 \\
BF Quality & 23 & 6.5 & 8.5 \\
BF Amin & 23 & 6.5 & 8.5 \\
Tytanit & 45 & 13 & 17 \\
Vinassa & 23 & 6.5 & 8.5 \\
\hline
\end{tabular}


the number and thickness of layers of spore walls [29] [31]. The shape and size of spores were determined on at least 50 intact spores mounted in a drop of water or lactic acid placed on a microscope slide. The dimensions were determined using a light microscope equipped with an ocular micrometer. The thickness of layers of spore walls and germination walls was measured in spores freshly isolated and crushed in PVLG or PVLG + Melzer's reagent $(1: 1 \mathrm{v} / \mathrm{v})$, and observed under a light microscope equipped with a micrometer eyepiece [29]. The observed AMF species were named according to Schüßler and Walker [32] and Błaszkowski [29].

\subsection{Determination of Strawberry Root Growth and Morphological Parameters}

At the end of the growth period, strawberry root dry weight was determined in accordance with the analytical procedure developed by Ostrowska et al. [33]. Root morphological parameters (total root length, root diameter, root surface area, root volume and total number of root tips) were measured by an image analysis system with an Epson scanner controlled by WinRhizo software (Regent Instruments Inc.). The degree of branching of the root system was calculated as the ratio between the total number of roots and their total length [34].

\subsection{Statistics}

The results were statistically evaluated by analysis of variance. Comparisons of means were done at $p \leq 0.05$ with the Duncan test. To compare the genetic diversity of mycorhizal species (mycorrhizal population numbers), the Shannon and derivative Equitability indexes were calculated using the PAST program. Pairwise correlations between mycorrhizal Frequency (F\%), Shannon index diversity, root growth and morphological parameters of strawberry plants were carried out using non-parametric Spearman rank statistics testing at $p<0.05$.

A Principal Component Analysis (PCA) was carried out on the mean number of spores per sample occurring in the roots of strawberry plants grown in rhizoboxes, treated with the mineral fertilizer (NPK) and the different soil and foliar fertilizers with the aim to identify relationships among the treatments and the abundance of spores. A PCA was carried out also considering the amount of nutrient elements provided with the different treatments, mycorrhizal frequency, diversity index ( $\left.\mathrm{H}^{\prime}\right)$ and morphological root parameters with the aim to identify latent relationships among them. These analyses were performed with SPSS statistics (version 21, IBM corporation).

\section{Results}

\subsection{Mycorrhizal Frequency in Strawberry as Affected by Fertilization Treatments}

The highest value of mycorrhizal frequency (F\%) was obtained for the treatment with the humate-based product (Humus Active: 38.89 ), followed by the vermicompost extract (Humus UP: 31.11), the yeast stillage (Vinassa: 29.21) and the microorganisms consortium (Micosat: 26.67) (Table 2). Vinassa induced also the highest values

Table 2. Mycorrhizal frequency (F\%) and mycorrhizal intensity (both relative $-\mathrm{M} \%$, and absolute $-\mathrm{m} \%$ ) determined in the roots of strawberry plants "Honeoye" grown in rhizoboxes treated with different mineral and organic fertilizers (means of 90 replicates; different letters within the same parameter indicate statistically significant difference $p \leq 0.05$ ).

\begin{tabular}{cccc}
\hline Treatments & F [\%] & M [\%] & m [\%] \\
\hline Control & $12.22 \mathrm{~b}$ & $0.26 \mathrm{a}$ & $2.00 \mathrm{a}$ \\
NPK & $5.56 \mathrm{a}$ & $0.06 \mathrm{a}$ & $1.00 \mathrm{a}$ \\
Manure & $7.78 \mathrm{ab}$ & $0.08 \mathrm{a}$ & $1.00 \mathrm{a}$ \\
Micosat & $26.67 \mathrm{c}$ & $1.49 \mathrm{a}$ & $6.05 \mathrm{a}$ \\
Humus UP & $31.11 \mathrm{~d}$ & $3.52 \mathrm{a}$ & $6.35 \mathrm{a}$ \\
Humus Active & $38.89 \mathrm{e}$ & $0.57 \mathrm{a}$ & $1.46 \mathrm{a}$ \\
BF Quality & $8.89 \mathrm{ab}$ & $0.82 \mathrm{a}$ & $8.11 \mathrm{a}$ \\
BF Amin & $13.33 \mathrm{~b}$ & $0.82 \mathrm{a}$ & $3.95 \mathrm{a}$ \\
Tytanit & $2.22 \mathrm{a}$ & $0.02 \mathrm{a}$ & $0.67 \mathrm{a}$ \\
Vinassa & $29.21 \mathrm{~cd}$ & $2.44 \mathrm{a}$ & $8.20 \mathrm{a}$ \\
\hline
\end{tabular}


of mycorrhizal intensity (m\%) (8.20), similar to the plant extract (BF Quality: 8.11), Humus UP (6.35), and Micosat (6.05). The lowest values of mycorrhizal frequency and intensity were obtained after the treatment with Tytanit and in the NPK control (Table 2).

\subsection{Spore Counting and Biodiversity}

The highest number of species of AM fungi was found in the treatment with manure ( 4 species), followed by the treatments with Humus Active, Tytanit and Vinassa (3 species) (Figure 1). The remaining fertilizers, including the zero control and the control fertilized with NPK, only two species of AM fungi were found. The most frequently found species, present in all the treatments, was Claroideoglomus claroideum (N. C. Schenck \& G. S. Sm.) C. Walker \& A. Schüßler comb nov. It was followed by Funneliformis mosseae (T. H. Nicolson \& Gerd.) C. Walker \& A. Schüßler comb nov., which was found in eight treatments with exception of the two controls (Table 3). The species Rhizophagus fasciculatus (Thaxt.) C. Walker \& A. Schüßler comb nov. was found in four treatments- the two controls, Humus Active, and Tytanit (Table 3). The species Scutellospora dipurpurescens J. B. Morton \& Koske was identified only in the plants treated with manure, while Funneliformis constrictum (Trappe) C. Walker \& A. Schüßler comb nov. was found in the plants treated with Vinassa (Table 3).

The production of spores in rhizospheric soil was statistically different only in the treatment with Humus Active (Table 4). All other treatments with organic fertilizers showed a trend in inducing a larger numbers of spores in comparison with the treatment with the mineral fertilizer (NPK), but it was not statistically significant. However, when pooling the averages of the spores produced by a group of species, irrespective of the number of treatments considered, it emerged that the two groups formed by Claroideoglomus claroideum and Funneliformis mosseae alone or with Rhizophagus fasciculatus formed a significantly higher number of spores in comparison to the other groups of species (Figure 1).

The diversity index $\mathrm{H}$ resulted with a value higher than 1 for the control and the treatments with soil fertilizers, except manure alone which showed a value lower than 1 (Table 5). All foliar treatments receiving also some manure (Tytanit, Vinassa and BF Amin) showed a similar reduced H value, with the exception of BF Quality. The equitability index $\mathrm{J}$ varied more, with all foliar treatments having a value lower than the control and the soil treatments higher than control, with the exception of manure alone (Table 5).

The two first components of the PCA on the effect of the different treatments on the number of spores resulted in a more than $70 \%$ description of the total variance (Figure 2). The products grouped into four groups. One

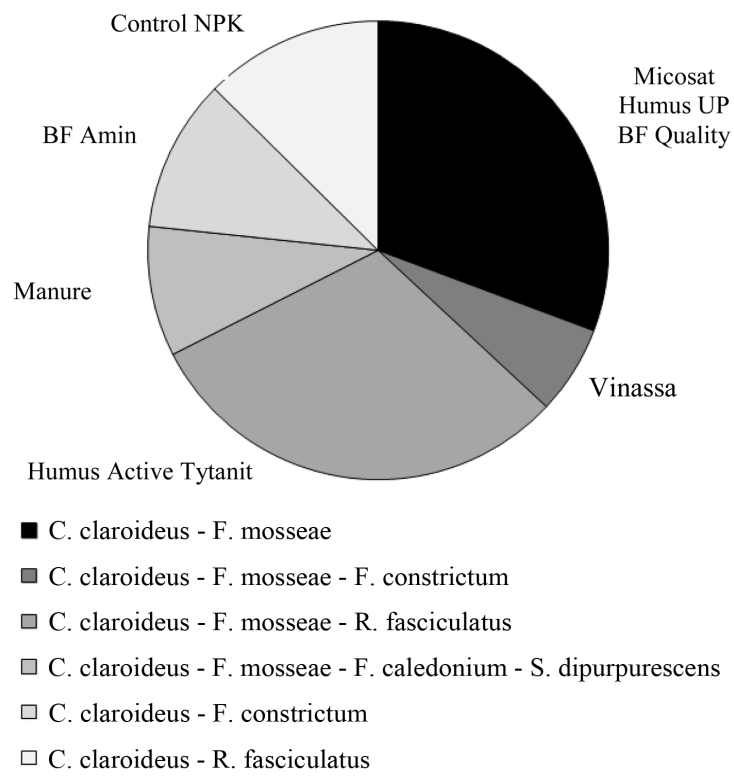

Figure 1. Average number of spores produced by the group of species detected in the rhizosphere of strawberry plants "Honeoye" grown in rhizoboxes treated with different mineral and organic fertilizers. 
Table 3. Species of arbuscular mycorrhizal fungi from strawberry plants rhizospheric soil isolated from pot trap cultures established with Plantago lanceolata.

\begin{tabular}{cc}
\hline Treatments & Species \\
\hline Control & Claroideoglomus claroideum \\
& Rhizophagus fasciculatus \\
NPK & Claroideoglomus claroideum \\
& Rhizophagus fasciculatus \\
& Claroideoglomus claroideum \\
Manure & Funneliformis mosseae \\
& Funneliformis caledonium \\
& Scutellospora dipurpurescens \\
Micosat & Claroideoglomus claroideum \\
& Funneliformis mosseae \\
Humus UP & Claroideoglomus claroideum \\
& Funneliformis mosseae \\
Humus Active & Claroideoglomus claroideum \\
& Funneliformis mosseae \\
& Rhizophagus fasciculatus \\
BF Quality & Claroideoglomus claroideum \\
& Funneliformis mosseae \\
BF Amin & Claroideoglomus claroideum \\
& Funneliformis constrictum \\
Tytanit & Claroideoglomus claroideum \\
& Funneliformis mosseae \\
& Rhizophagus fasciculatus \\
& Claroideoglomus claroideum \\
& Funneliformis mosseae \\
& Funeliformis constrictum \\
\hline &
\end{tabular}

Table 4. Average number of spores isolated from trap cultures containing rhizospheric soil of strawberry plants receiving different mineral and organic fertilizers (means of 3 replicates; different letters indicate statistically significant differences between the applied treatments $p \leq 0.05$ ).

\begin{tabular}{cc} 
Treatment & Mean number of spores per sample $(100 \mathrm{~g})$ \\
\hline Control & $297.00 \mathrm{a}$ \\
NPK & $136.66 \mathrm{a}$ \\
Manure & $317.33 \mathrm{a}$ \\
Micosat & $308.66 \mathrm{a}$ \\
Humus UP & $300.00 \mathrm{a}$ \\
Humus Active & $860.33 \mathrm{~b}$ \\
BF Quality & $451.66 \mathrm{a}$ \\
BF Amin & $372.00 \mathrm{a}$ \\
Tytanit & $196.33 \mathrm{a}$ \\
Vinassa & $216.33 \mathrm{a}$ \\
\hline
\end{tabular}

composed of the foliar treatments with organic products (i.e. BF Amin, BF Quality and Vinassa) which grouped closely to the Control and to the soil treatment Humus Active. Two groups were formed by two products each: Tytanit and Manure, Micosat and Humus UP. The mineral fertilizer NPK was separated from all other treatments. 
Table 5. Diversity $(\mathrm{H})$ and equitability $(\mathrm{J})$ indexes of mycorrhizal spore populations occurring in the roots of strawberry plants cv. "Honeoye" grown in rhizoboxes and treated with different mineral and organic soil and foliar fertilizers.

\begin{tabular}{cccc}
\hline Treatment & $\mathrm{H}$ & $\mathrm{J}$ & $\mathrm{J} / \mathrm{H}$ \\
\hline Control & 1.001 & 0.9112 & 0.9103 \\
NPK & 1.096 & 0.9972 & 0.9099 \\
Manure & 0.9271 & 0.8439 & 0.9103 \\
Micosat & 1.016 & 0.9246 & 0.9100 \\
Humus UP & 1.092 & 0.9944 & 0.9106 \\
Humus Active & 1.024 & 0.9318 & 0.9100 \\
BF Quality & 1.001 & 0.9107 & 0.9098 \\
BF Amin & 0.7906 & 0.7196 & 0.9102 \\
Tytanit & 0.9396 & 0.8553 & 0.9103 \\
Vinassa & 0.9285 & 0.8452 & 0.9103 \\
\hline
\end{tabular}

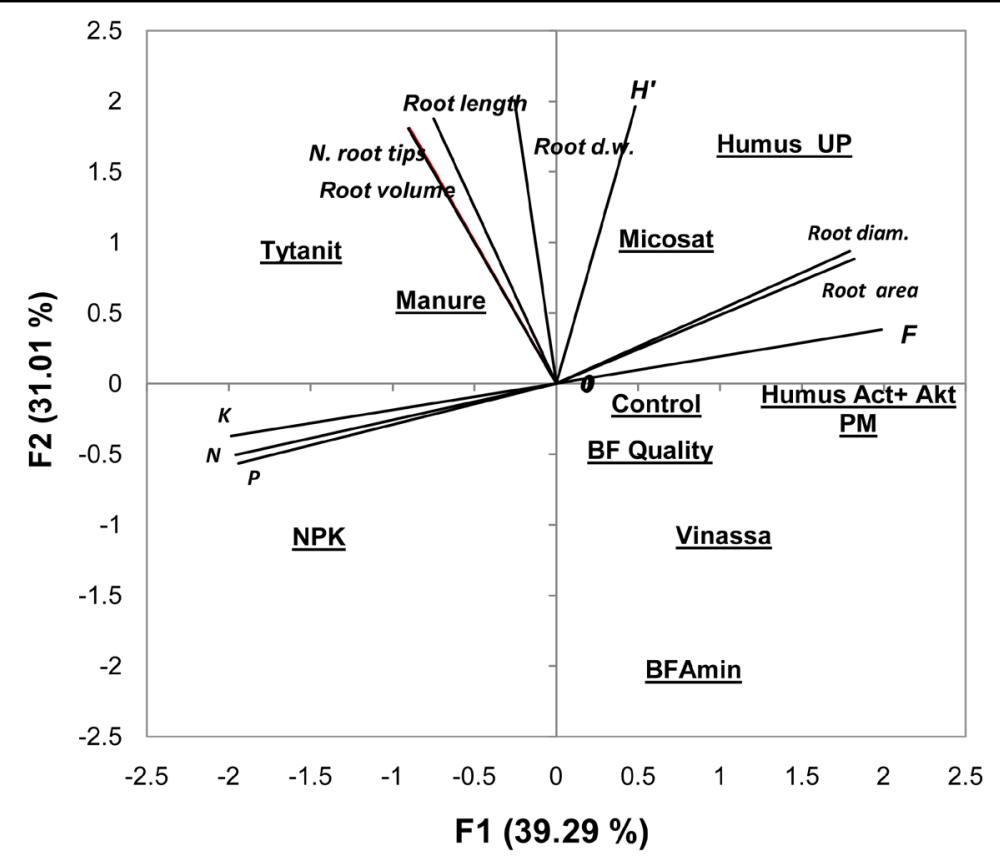

Figure 2. Bi-plot showing the effect of the fertilization treatments on the number of spores (underlined) and with the relationships between the amount of mineral elements provided by the fertilizers and the root mycorrhizal and morphological parameters (italic) elaborated by Principal Components Analysis.

\subsection{Effect of Fertilizers on Root Parameters}

All organic fertilizers affected the growth and morphology of roots (Table 6). The highest dry weight of roots was obtained in the plants treated with Humus UP, while the lowest was induced by NPK and BF Amin; all other treatments showed an intermediate growth, similar to the control. Among the soil fertilizers, the application of Micosat and Humus UP promoted a good development of the root system with plants showing the highest surface area, volume, total length and number of root tips. BF Amin was instead the product inducing the smallest root development, showing almost always the lowest value for the root growth and morphological parameters. The other products showed generally an intermediate effect, affecting in different way the parameters measured, 
Table 6. Root growth and morphological parameters of strawberry plants cv. "Honeoye" treated with different bioproducts (means of 3 replicates; different letters within the same parameter indicate statistically significant differences $p \leq 0.05$ ).

\begin{tabular}{cccccccc}
\hline Treatments & Rhizosphere pH & $\begin{array}{c}\text { Root dry } \\
\text { weight }[\mathrm{g}]\end{array}$ & $\begin{array}{c}\text { Root surface } \\
\text { area }\left[\mathrm{cm}^{2}\right]\end{array}$ & $\begin{array}{c}\text { Root volume } \\
{\left[\mathrm{cm}^{3}\right]}\end{array}$ & $\begin{array}{c}\text { Root length } \\
{[\mathrm{cm}]}\end{array}$ & $\begin{array}{c}\text { Number of } \\
\text { root tips }\end{array}$ & $\begin{array}{c}\text { Root branching } \\
\text { index }\end{array}$ \\
\hline Control & $5.2 \mathrm{a}$ & $2.4 \mathrm{ab}$ & $522 \mathrm{ab}$ & $7.44 \mathrm{ab}$ & $2927 \mathrm{~b}$ & $6427 \mathrm{c}$ & $2.2 \mathrm{c}$ \\
NPK & $5.8 \mathrm{~b}$ & $1.7 \mathrm{a}$ & $466 \mathrm{ab}$ & $7.89 \mathrm{ab}$ & $2869 \mathrm{~b}$ & $4758 \mathrm{~b}$ & $1.7 \mathrm{a}$ \\
Manure & $5.9 \mathrm{~b}$ & $2.2 \mathrm{ab}$ & $530 \mathrm{ab}$ & $11.39 \mathrm{~b}$ & $3784 \mathrm{c}$ & $6513 \mathrm{c}$ & $1.8 \mathrm{a}$ \\
Micosat & $6.2 \mathrm{c}$ & $2.7 \mathrm{~b}$ & $728 \mathrm{~b}$ & $10.17 \mathrm{~b}$ & $3585 \mathrm{c}$ & $7674 \mathrm{~cd}$ & $2.1 \mathrm{c}$ \\
Humus UP & $5.9 \mathrm{~b}$ & $2.8 \mathrm{~b}$ & $673 \mathrm{~b}$ & $11.17 \mathrm{~b}$ & $3622 \mathrm{c}$ & $6870 \mathrm{c}$ & $1.9 \mathrm{~b}$ \\
Humus Active & $6.3 \mathrm{c}$ & $1.5 \mathrm{a}$ & $707 \mathrm{~b}$ & $8.57 \mathrm{ab}$ & $3029 \mathrm{~b}$ & $5561 \mathrm{bc}$ & $1.9 \mathrm{~b}$ \\
BF Quality & $5.9 \mathrm{~b}$ & $1.9 \mathrm{ab}$ & $567 \mathrm{ab}$ & $7.47 \mathrm{ab}$ & $2664 \mathrm{~b}$ & $6035 \mathrm{bc}$ & $2.3 \mathrm{c}$ \\
BF Amin & $6.2 \mathrm{c}$ & $1.2 \mathrm{a}$ & $498 \mathrm{ab}$ & $5.51 \mathrm{a}$ & $1955 \mathrm{a}$ & $3891 \mathrm{a}$ & $2.0 \mathrm{~b}$ \\
Tytanit & $6.1 \mathrm{c}$ & $2.2 \mathrm{ab}$ & $366 \mathrm{a}$ & $10.56 \mathrm{~b}$ & $3923 \mathrm{c}$ & $7991 \mathrm{~d}$ & $2.1 \mathrm{c}$ \\
Vinassa & $6.6 \mathrm{~d}$ & $1.6 \mathrm{ab}$ & $721 \mathrm{~b}$ & $7.34 \mathrm{ab}$ & $2396 \mathrm{a}$ & $4344 \mathrm{~b}$ & $1.8 \mathrm{a}$ \\
\hline
\end{tabular}

and in several cases not different from the control Vinassa induced the largest root surface area, while manure, alone or with addition of Tytanit, very positively affected the total length of roots. No differences were found in the diameter of the roots, being after all treatments on average $0.59 \mathrm{~mm}$ (data not shown). Interestingly, the highest root branching index was found for Micosat, BF Quality and Tytanit, not different from the control. The other fertilizers induced a lower index in comparison to the control, with NPK, Manure and Vinassa significantly different from all treatments. Both soil and foliar fertilizers significantly increased the $\mathrm{pH}$ measured in the rhizosphere zone. The most alkaline values were associated to the treatment with Vinassa (about 1.5 units more); Micosat, Humus Active, BF Amin and Tytanit increased the $\mathrm{pH}$ of about 1 point, while the remaining treatments modified less the value (Table 6).

The PCA evaluating the relations among the nutrients provided by the different treatments and the mycorrhizal and morphological root parameters showed a striking separation of the different parameters (Figure 2). The nutrients grouped opposite from the mycorrhizal and root parameters, suggesting a negative relation between these parameters. The frequency of mycorrhizal colonization grouped together with root surface area and diameter, while the other morphological root parameters formed a third separate group together with the diversity index.

\section{Discussion}

The treatment of the soil and strawberry plants with products based on very different substances (microbial inocula, seaweed or plants extracts, humic extracts, animal manure) exerted a very diverse effect on AMF inoculation, sporulation, AMF diversity and root growth.

The plants treated with the products containing humic extract (Humus Active, Humus UP) showed a very high colonization ratio (Table 3) and high root growth (Table 6). Gryndler et al. [35] found that humic substances stimulated root colonization and production of extraradical mycelium by Glomus claroideum (currently classified as Claroideoglomus claroideum) in a hydroponic system. Humic substances, similar to those of Humus UP, can be taken up by plants and actively modify the plant metabolism, promoting nutrient uptake or acting as hormone-like substances [36]. The higher growth could thus also be induced by the higher rate of macro- and micro-nutrients acquisition by plants treated with humic substances [37] [38].

Application of the seaweed extract (BF Quality) or plant extract (BF Amin) did not give positive effect on total root colonisation by AMF (Table 3). Low AMF colonization rate was observed by [9] when passion fruit plants were treated with seaweed Gracilaria verrucosa extract, while this extract stimulated root colonization in papaya. Seaweed active compounds can stimulate AMF hyphae growth in vitro [8] and enhance plant root colonization when applied into soil [8] [39], but it was shown that some substances present in seaweed can also inhibit AMF hyphae growth [40]. Kahydrin is a derivate of the vitamin K normally present in seaweed extracts; its exogenous application induced the acidification of rhizosphere [41] which can affect root colonization rate by 
AMF [42] [43].

The stillage derived from the yeast production (Vinassa) had the greatest positive influence on the colonization of strawberry roots by AMF. The product is rich in yeast cell components, including several aminoacids and other compounds (e.g. betaine) which are released by the yeasts during their growth. Singh et al. [44] reported that yeasts or just their soluble exudates stimulated the percentage of soybean roots colonized by AMF and also the percentage of spore germination and hyphal growth [45]. This occurred particularly when the yeasts were inoculated as an aqueous solution. similarly to the method applied in the trial of ours. All the three products, being alkaline, induced also a significant increase of the rhizosphere $\mathrm{pH}$ (Table 6). Application of the yeast stillage Vinassa, which induced the higher rhizosphere $\mathrm{pH}$, increased also AMF species diversity in the rhizosphere. Liming acidic soils tends to increase mycorrhizal population density and may result in a change in species dominance [46] [47]. On the other hand, a pH closer to neutral seems not to affect the AMF species present [48] [49].

Fertilization with NPK and Manure significantly reduced mycorrhizal frequency. Use of readily soluble fertilisers, particularly $\mathrm{N}$ fertilisers, as well as $\mathrm{P}$ fertilizers, has been reported to have a negative impact on AM colonisation and/or diversity in some cases [50]-[54]. The latter effect has been observed also in our trial, since after application of NPK only the two most frequent species (Claroideoglomus claroideum and Rhizophagus fasciculatus) were present in the trap culture (Table 3). The limited root colonization and diversity of species present after the treatment with Manure was partly unexpected since farmyard manure does not seem to suppress AMF and may even stimulate them [50] [55]-[57]. However, overuse of organic amendments, especially those high in P, may impact negatively on AMF and the precise effect of organic amendments has been shown to be unpredictable on any given soil or with any particular amendment [58] [59]. Fertilisation may also select AMF species that are inferior in terms of providing a benefit to the host [60].

Root growth and morphology was strongly affected by the different treatments. The humic extract from vermicompost (Humus UP) and the microbial consortium (Micosat), which were characterized by the lowest content of nutrient elements, induced the highest root growth (Table 6). In case of the microbial consortium, this effect can be due to the growth promotion effect of the bacteria species present and/or to the positive effect derived from the high root colonization by the mycorrhizal fungi (Table 3). Nevertheless, it is interesting to note that only two AMF species were isolated by the trap cultures of the rhizospheric soil treated with both products and among them was present the ubiquitous Claroideoglomus claroideum. We can hypothesize that in case of Micosat the addition of the consortium formed of PGPR and other beneficial microorganisms has well interacted with the autochthonous AMF species of the soil to provide an improved growth of the plants. Such effect has been reported by several authors with different plants [12]. The application of Vinassa resulted also in an increased root growth in comparison to control (Table 2 and Table 3). The positive effect of Vinassa on root development has been proved also in other crops [61].

The different products induced modification also of the root system morphology. Two products provided as foliar sprays (i.e. BF Quality and BF Amin) induced a limited development of the root system, similarly to the control or NPK treatment, particularly of the number of root tips (Table 2). Plants treated with seaweed extract have been reported to show changes in the root system architecture [62]. Application of foliar fertilizers, similarly to that of the current experiment, was shown to modify both the rhizosphere $\mathrm{pH}$ and the root growth [63]. Leaf applied amino acids from plant extracts can be utilized in leaf blades and not transferred into roots, causing no effects on root growth [64].

The treatment with Micosat, a consortium of AMF and other rhizosphere microorganisms, increased the development of roots and root branching (Table 6). Norman et al. [65] observed that strawberry plants cv. "Elsanta", "Cambridge favourite" and "Rhapsody" inoculated with AMF increased root weight, and root colonisation, three months after inoculation. Inoculation increased number of root branches, especially for "Elsanta" and "Rhapsody". Only "Cambridge favourite" inoculated with Glomus fasciculatum has not increased branching.

The effect of titanium, the only nutrient present in the product Tytanit, is mainly related to the increase photosynthetic efficiency [66], therefore we hypothesize that its effect on root growth can be linked to the general better development of the plant even with only half dose of soil nutrient availability.

The correlation found among root diameter, surface area and mycorrhizal frequency (Figure 2) is underlining the effect of AMF inoculation on root morphology [34]. Similarly, the negative relations found between the amount of nutrients and root growth parameters and mycorrhizal inoculation is confirming the negative effect of mineral fertilization on the growth of the root system and on the establishment of the mycorrhizal symbiosis [54]. 
The number of AM fungal spores recovered from the soil was within the range of spore densities found in other cultivated agricultural soils, both conventionally and organically managed, [67]-[70]. However, it is also clear from our results that the application of organic fertilizers does not necessarily result in large numbers of AM fungal spores in absolute terms. Even though the lowest number of spores was observed in NPK fertilized and in Tytanit treatments, only the application of the vermicompost extract Humus Active induced a significant increase of spore formation (Table 5). Spore formation is a process that is normally increased under conditions of low availability of mineral nutrients [71] [72]. Therefore, we can hypothesize that the conditions of plant growth were sufficient to support the growth of the hyphae without switching into the production of resistance organs such as spores. On the other hand, consistent with this hypothesis, the treatment with Humus Active provided the lowest amount of nitrogen and phosphorous and induced the lowest root growth, while inducing very much inoculation and sporulation of AMF (Table 2, Table 3 and Table 5). Nevertheless, even though there has been some reports about the factors impacting on spores numbers and colonization [73], the two group of species that produced on average the highest number of spores (i.e. C. claroideum and F. mosseae with or without $R$. fasciculatus) were not associated with a specific treatment, thus not possible to relate to their effect (Figure 1). These results also confirm the fact that spore numbers are not a good indicator of the colonisation potential of a soil [67] [69].

The different treatments affected also the species of mycorrhizal fungi present in the rizhosphere (Table 4). The most frequent species found in our trial, F. mosseae, is the third most frequently occurring arbuscular fungal species in Poland and it markedly preferred cultivated soils [74]. The species was missing only in the rhizosphere of untreated plants and when plants received mineral fertilization (Table 4). However, also the other species that were isolated from the rhizospheric soil of strawberries are very frequent species in Poland [29] [74]. Interestingly, both Funneliformis caledonium and S. dipurpurescens, which were found only when manure was singly applied to the soils, are found particularly in sandy soils [74], where the presence of organic matter is critical to plant growth.

The research about influence of bioproducts mentioned above on soil mycorrhizal communities of strawberry plants will be carried out in field conditions.

\section{Conclusion}

The influence of the different products on the development of AMF symbiosis in "Honeoye" strawberry plants and on the resulting root development could be related to their chemical and biological characteristics. The bioproducts based on vermicompost extracts (Humus Active and Humus UP) and the yeast stillage (Vinassa) had the greatest positive influence on the colonization of roots by AMF. The different treatments affected the diversity of AMF species present in the rhizospheric soil, which could be considered as an additional feature for assessing the effect on the soil biodiversity due to these agronomical means. Generally, all organic products positively affected root growth characteristics, even in comparison to the standard mineral fertilization (NPK), but some of them (e.g. Humus UP, Vinassa and BF Quality) were on average more efficient than others.

\section{Acknowledgements}

We thank Prof. Janusz Błaszkowski from the West Pomeranian University of Technology in Szczecin for the help in classifying the spores isolated from trap cultures.

The work has been supported by a grant from the EU Regional Development Fund through the Polish Innovation Economy Operational Program, contract No. UDA-POIG.01.03.01-10-109/08-00.

\section{References}

[1] Barak, P., Jobe, B., Krueger, A., Peterson, L. and Laird, D. (1997) Effects of Long-Term Soil Acidification Due to Nitrogen Fertilizer Inputs in Wisconsin. Plant and Soil, 197, 61-69. http://dx.doi.org/10.1023/A:1004297607070

[2] Marschner, P., Kandeler, E. and Marschner, B. (2003) Structure and Function of the Soil Microbial Community in a Long-Term Fertilizer Experiment. Soil Biology and Biochemistry, 35, 453-461. http://dx.doi.org/10.1016/S0038-0717(02)00297-3

[3] Malusá, E., Sas Paszt, L., Głuszek, S. and Ciesielska, J. (2014) Organic Fertilizers to Sustain Soil Fertility. In: Sinha, S. and Pant, K., Eds., "Fertilizers Technology Vol. 1: Synthesis", Publishers Studium Press LLC, Houston, USA, 256-281.

[4] Kauffman, G.L., Kneivel, D.P. and Watschke, T.L. (2007) Effects of a Biostimulant on the Heat Tolerance Associated 
with Photosynthetic Capacity, Membrane Thermostability, and Polyphenol Production of Perennial Ryegrass. Crop Science, 47, 261-267. http://dx.doi.org/10.2135/cropsci2006.03.0171

[5] Corte, L., Dell'Abate, M.T., Magini, A., Migliore, M., Felici, B., Roscini, L., Sardella, R., Tancini, B., Emiliani, C., Cardinali, G. and Benedetti, A. (2013) Assessment of Safety and Efficiency of Nitrogen Organic Fertilizers from Animal-Based Protein Hydrolysates-A Laboratory Multidisciplinary Approach 2013. Journal of the Science Food Agriculture, 94, 235-245. http://dx.doi.org/10.1002/jsfa.6239

[6] Craigie, J. (2011) Seaweed Extract Stimuli in Plant Science and Agriculture. Journal of Applied Phycology, 23, 371393. http://dx.doi.org/10.1007/s10811-010-9560-4

[7] Wally, O.D., Critchley, A., Hiltz, D., Craigie, J., Han, X., Zaharia L.I., Abrams, S. and Prithiviraj, B. (2013) Regulation of Phytohormone Biosynthesis and Accumulation in Arabidopsis Following Treatment with Commercial Extract from the Marine Macroalga Ascophyllum nodosum. Journal of Plant Growth Regulation, 32, 324-339. http://dx.doi.org/10.1007/s00344-012-9301-9

[8] Kuwada, K., Kuramoto, M., Utamura, M., Matsushita, I., Shibata, Y. and Ishii, T. (2005) Effect of Mannitol from Laminaria japonica, Other Sugar Alcohols, and Marine Alga Polysaccharides on in Vitro Hyphal Growth of Gigaspora margarita and Root Colonization of Trifoliate Orange. Plant and Soil, 276, 279-286. http://dx.doi.org/10.1007/s11104-005-4985-2

[9] Kuwada, K., Wamocho, L.S., Utamur, M., Matsushita, I. and Ishii, T. (2006) Effect of Red and Green Algal Extracts on Hyphal Growth of Arbuscular Mycorrhizal Fungi, and on Mycorrhizal Development and Growth of Papaya and Passionfruit. Agronomy Journal, 98, 1340-1344. http://dx.doi.org/10.2134/agronj2005.0354

[10] Chen, J. (2006) The Combined Use of Chemical and Organic Fertilizers and/or Biofertilizer for Crop Growth and Soil Fertility. International Workshop on Sustained Management of the Soil-Rhizosphere System for Efficient Crop Production and Fertilizer Use, Bangkok, 1-11.

[11] Smith, S.E. and Read, D.J. (2008) Mycorrhizal Symbiosis. 3rd Edition, Elsevier and Academic, New York, London, Burlington, San Diego.

[12] Bardi, L. and Malusá, E. (2012) Drought and Nutritional Stresses in Plant: Alleviating Role of Rhizospheric Microorganisms. In: Haryana, N. and Punj, S., Eds., Abiotic Stress: New Research, Nova Science Publishers, Inc., Hauppauge, $1-57$.

[13] Dunne, M.J. and Fitter, A.H. (1989) The Phosphorus Budget of Field-Grown Strawberry (Fragaria x ananassa cv. Hapil) Crop: Evidence for a Mycorrhizal Contribution. Annals of Applied Biology, 114, 185-193. http://dx.doi.org/10.1111/j.1744-7348.1989.tb06799.x

[14] Sas Paszt, L. and Żurawicz, E. (2005) Studies of the Rhizosphere of Strawberry Plants at the Research Institute of Pomology and Floriculture in Skierniewice, Poland. International Journal of Plant Science, 5, 115-126.

[15] Derkowska, E., Sas Paszt, L., Sumorok, B., Szwonek, E. and Głuszek, S. (2008) The Influence of Mycorrhization and Organic Mulches on Mycorrhizal Frequency in Apple and Strawberry Roots. Journal Fruit Ornamental Plant Research, 16, 227-242.

[16] Didier, M.F., Hamel, C., Dalpé, Y. and Khanizadeh, S. (2003) Diversity of Native Endomycorrhizal Fungi in Selected Strawberry Field Soils of Southern Quebec. Small Fruits Review, 2, 61-71. http://dx.doi.org/10.1300/J301v02n02_05

[17] Botham, R., Collin, C. and Ashman, T. (2009) Plant-Mycorrhizal Fungus Interactions Affect the Expression of Inbreeding Depression in Wild Strawberry. International Journal of Plant Science, 170, 143-150. http://dx.doi.org/10.1086/595284

[18] Sas Paszt, L., Sumorok, B., Malusá, E., Głuszek, S. and Derkowska, E. (2011) The Influence of Bioproducts on Root Growth and Mycorrhizal Occurrence in the Rhizosphere of Strawberry Plants cv. "Elsanta". Journal of Fruit and Ornamental Plant Research, 19, 13-34.

[19] Azcón-Aquilar, C. and Barea, J.M. (1992) Interactions between Mycorrhizal Fungi and Other Rhizosphere Microorganisms. In: Allen, M.J., Ed., Mycorrhizal Functioning. An Integrative Plant-Fungal Process, CH Publishing, Ottawa, Canada, 163-198.

[20] Oehl, F., Sieverding, E., Mader, P., Dubois, D., Ineichen, K., Boller, T. and Wiemken, A. (2004) Impact of Long-Term Conventional and Organic Farming on the Diversity of Arbuscular Mycorrhizal Fungi. Oecologia, 138, 574-583. http://dx.doi.org/10.1007/s00442-003-1458-2

[21] Borowicz, V.A. (2010) The Impact of Arbuscular Mycorrhizal Fungi on Strawberry Tolerance to Root Damage and Drought Stress. Pedobiologia, 53, 265-270. http://dx.doi.org/10.1016/i.pedobi.2010.01.001

[22] Li, H., Smith, F.A., Dickson, S., Holloway, R.E. and Smith, S.E. (2008) Plant Growth Depressions in Arbuscular Mycorrhizal Symbioses: Not Just Caused by Carbon Drain? New Phytologist, 178, 852-862. http://dx.doi.org/10.1111/j.1469-8137.2008.02410.x

[23] Schroeder, M.S. and Janos, D.P. (2004) Phosphorus and Intraspecific Density Alter Plant Responses to Arbuscular 
Mycorrhizas. Plant and Soil, 264, 335-348. http://dx.doi.org/10.1023/B:PLSO.0000047765.28663.49

[24] Gosling, P., Hodge, A., Goodlass, G. and Bending, G.D. (2006) Arbuscular Mycorrhizal Fungi and Organic Farming. Agriculture, Ecosystems \& Environment, 113, 17-35. http://dx.doi.org/10.1016/j.agee.2005.09.009

[25] Philips, J.M. and Hayman, D.A. (1970) Improved Procedures for Clearing Roots and Staining Parasitic and VesicularArbuscular Mycorrhizal Fungi for Rapid Assessment of Infection. Transactions of the British Mycological Society, 55, 158-161. http://dx.doi.org/10.1016/S0007-1536(70)80110-3

[26] Turnau, K., Ryszka, P., Gianinazzi-Pearson, V. and van Tuinen, D. (2001) Identification of Arbuscular Mycorrhizal Fungi in Soils and Roots of Plants Colonizing Zinc Wastes in Southern Poland. Mycorrhiza, 10, 169-174. http://dx.doi.org/10.1007/s005720000073

[27] Sumorok, B., Michalska-Hejduk, D. and Sas Paszt, L. (2008) Badania mikoryz u roślin zbiorowisk okresowo zalewanych. In: Mułenko, W., Ed., Mikologiczne badania terenowe. Przewodnik metodyczny, Wydawnictwo UMCS, Lublin, Poland, 132-141.

[28] Trouvelot, A., Kough, J.L. and Gianinazzi-Pearson, V. (1986) Mesure du taux de mycorhization VA d'un systeme radiculaire. Recherche de methods d'estimation ayant une signification fonctionnelle. In: Gianinazzi-Pearson, V., Gianinazzi, S., Eds., Physiological and Genetical Aspects of Mycorrhizae, INRA, Paris, 217-221.

[29] Błaszkowski, J. (2003) Arbuscular Mycorrhizal Fungi (Glomeromycota). Endogone and Complexipes Species Deposited in the Department of Plant Pathology, University of Agriculture in Szczecin, Poland. http://www.zor.zut.edu.pl/Glomeromycota/

[30] Brundrett, M.C., Bougher, N., Dell, B., Grove, T. and Malajczuk, N. (1996) Working with Mycorrhizas in Forestry and Agriculture. ACIAR Monograph Series, Pirie Printers, Canberra, 374.

[31] Błaszkowski, J. (2008) Metody izolowania, hodowania i identyfikowania arbuskularnych grzybów mikoryzowych z gromady Glomeromycota. In: Mułenko, W., Ed., Mikologiczne badania terenowe. Przewodnik metodyczny, Wydawnictwo UMCS, Lublin, Poland, 142-163.

[32] Schüßler, A. and Walker, C. (2010) The Glomeromycota: A Species List with New Families and New Genera. Schüßler, A., Walker, C., Gloucester, published in libraries at Royal Botanic Garden Edinburgh, Kew, Botanische Staatssammlung Munich, and Oregon State University. www.amf-phylogeny.com

[33] Ostrowska, A., Gawliński, S. and Szczubiałka, Z. (1991) Metody analizy i ocen właściwości gleb i roślin. Instytut Ochrony Środowiska, Warszawa, Poland.

[34] Berta, G., Trotta, A., Fusconi, A., Hooker, J., Munro, M., Atkinson, D., Giovannetti, M., Marini, S., Fortuna, P., Tisserant, B., Gianinazzi-Pearson, V. and Gianinazzi, S. (1995) Arbuscular Mycorrhizal Induced Changes to Plant Growth and Root System Morphology in Prunus cerasifera. Tree Physiology, 15, 281-293. http://dx.doi.org/10.1093/treephys/15.5.281

[35] Gryndler, M., Hršelová, H., Sudová, R., Gryndlerová, H., Řezáčová, V. and Merhautová, V. (2005) Hyphal Growth and Mycorrhiza Formation by the Arbuscular Mycorrhizal Fungus Glomus claroideum BEG 23 Is Stimulated by Humic Substances. Mycorrhiza, 15, 483-488. http://dx.doi.org/10.1007/s00572-005-0352-7

[36] Nardi, S., Pizzeghello, D., Muscolo, A. and Vianello, A. (2002) Physiological Effects of Humic Substances on Higher Plants. Soil Biology \& Biochemistry, 34, 1527-1536. http://dx.doi.org/10.1016/S0038-0717(02)00174-8

[37] Ayuso, M., Hernandez, T., Garcia, C. and Pascual, J.A. (1996) Stimulation of Barley Growth and Nutrient Absorption by Humic Substances Originating from Various Organic Materials. Bioresource Technology, 57, 251-257. http://dx.doi.org/10.1016/S0960-8524(96)00064-8

[38] Tahir, M.M., Khurshid, M., Khan, M.Z., Abbasi, M.K. and Kazmi, M.H. (2011) Lignite-Derived Humic Acid Effect on Growth of Wheat Plants in Different Soils. Pedosphere, 21, 124-131. http://dx.doi.org/10.1016/S1002-0160(10)60087-2

[39] Kuwada, K., Kuramoto, M., Utamura, M., Matsushita, I. and Ishii, T. (2006) Isolation and Structural Elucidation of a Growth Stimulant for Arbuscular Mycorrhizal Fungus from Laminaria japonica Areschoug. Journal of Applied Phycology, 18, 795-800. http://dx.doi.org/10.1007/s10811-006-9095-x

[40] Kuwada, K., Ishii, T., Matsushita, I., Matsumoto, I. and Kadoya, K. (1999) Effect of Seaweed Extracts on Hyphal Growth of Vesicular-Arbuscular Mycorrhizal Fungi and Their Infectivity on Trifoliate Orange Roots. Journal of the Japanese Society for Horticultural Science, 68, 321-326. http://dx.doi.org/10.2503/jishs.68.321

[41] Luthje, S. and Bottger, M. (1995) On the Function of a K-Type Vitamin in Plasma Membranes of Maize (Zea mays L.) Roots. Mitteilungen Aus Dem Institut für Allgemeine Botanik der Universitat Hamburg, 25, 5-13.

[42] Bansal, M. and Mukerji, K.G. (1994) Positive Correlation between AM-Induced Changes in Root Exudation and Mycorrhizosphere Mycoflora. Mycorrhiza, 5, 39-44. http://dx.doi.org/10.1007/BF00204018

[43] Bücking, H., Abubaker, J., Govindarajulu, M., Tala, M., Pfeffer, P.E., Nagahashi, G., Lammers, P. and Shachar-Hill, Y. 
(2008) Root Exudates Stimulate the Uptake and Metabolism of Organic Carbon in Germinating Spores of Glomus intraradices. New Phytologist, 180, 684-695. http://dx.doi.org/10.1111/j.1469-8137.2008.02590.x

[44] Singh, G.S., Kapoor, A. and Wange, S.S. (1991) The Enhancement of Root Colonisation of Legumes by VesicularArbuscular Mycorrhizal (VAM) Fungi Through the Inoculation of the Legume Seed with Commercial Yeast (Saccharomyces cerevisiae). Plant and Soil, 131, 129-133.

[45] Sampedro, I., Aranda, E., Scervino, J.M., Fracchia, S., Garcia-Romera, I., Ocampo, J.A. and Godeas, A. (2004) Improvement by Soil Yeasts of Arbuscular Mycorrhizal Symbiosis of Soybean (Glycine max) Colonized by Glomus mosseae. Mycorrhiza, 14, 229-234. http://dx.doi.org/10.1007/s00572-003-0285-y

[46] Hamel, C., Dalpé, Y., Lapierre, C., Simard, R.R. and Smith, D.L. (1994) Composition of the Vesicular-Arbuscular Mycorrhizal Fungi Population in an Old Meadow as Affected by $\mathrm{pH}$, Phosphorus and Soil Disturbance. Agriculture, Ecosystems \& Environment, 49, 223-231. http://dx.doi.org/10.1016/0167-8809(94)90051-5

[47] Nurlaeny, N., Marschner, H. and George, E. (1996) Effects of Liming and Mycorrhizal Colonization on Soil Phosphate Depletion and Phosphate Uptake by Maize (Zea mays L.) and Soybean (Glycine max L.) Grown in Two Tropical Acid Soils. Plant and Soil, 181, 275-285. http://dx.doi.org/10.1007/BF00012062

[48] Wang, G.M., Stribley, D.P., Tinker, P.B. and Walker, C. (1993) Effects of pH on Arbuscular Mycorrhiza. I. Field Observations on the Long-Term Liming Experiments at Rothamsted and Wobum. New Phytologist, 124, 465-472. http://dx.doi.org/10.1111/j.1469-8137.1993.tb03837.x

[49] Bermudez, M. and Azcón, R. (1996) Calcium Uptake by Alfalfa as Modified by a Mycorrhizal Fungus and Liming. Symbiosis, 20, 175-184.

[50] Miller, R.L. and Jackson, L.E. (1998) Survey of Vesicular-Arbuscular Mycorrhizae in Lettuce Production in Relation to Management and Soil Factors. The Journal of Agricultural Science, 130, 173-182. http://dx.doi.org/10.1017/S0021859697005212

[51] Liu, A., Hamel, C., Hamilton, R.I., Ma, B.L. and Smith, D.L. (2000) Acquisition of Cu, Zn, Mn and Fe by Mycorrhizal Maize (Zea mays L.) Grown in Soil at Different P and Micronutrient Levels. Mycorrhiza, 9, 331-336. http://dx.doi.org/10.1007/s005720050277

[52] Kahiluoto, H., Ketoja, E., Vestberg, M. and Saarela, I. (2001) Promotion of AM Utilization through Reduced P Fertilization 2. Field Studies. Plant and Soil, 231, 65-71. http://dx.doi.org/10.1023/A:1010366400009

[53] Burrows, R.L. and Pfleger, F.L. (2002) Arbuscular Mycorrhizal Fungi Respond to Increasing Plant Diversity. Canadian Journal of Botany, 80, 120-130. http://dx.doi.org/10.1139/b01-138

[54] Treseder, K.K. and Allen, M.F. (2002) Direct Nitrogen and Phosphorus Limitation of Arbuscular Mycorrhizal Fungi: A Model and Field Test. New Phytologist, 155, 507-515. http://dx.doi.org/10.1046/j.1469-8137.2002.00470.x

[55] Harinikumar, K.M. and Bagyaraj, D.J. (1989) Effect of Cropping Sequence, Fertilizers and Farmyard Manure on Vesicular-Arbuscular Mycorrhizal Fungi in Different Crops over Three Consecutive Seasons. Biology \& Fertility of Soils, 7, 173-175. http://dx.doi.org/10.1007/BF00292578

[56] Ryan, M.H., Chilvers, G.A. and Dumaresq, D.C. (1994) Colonisation of Wheat by VA-Mycorrhizal Fungi Was Found to Be Higher on a Farm Managed in an Organic Manner than on a Conventional Neighbor. Plant and Soil, 160, 33-40. http://dx.doi.org/10.1007/BF00150343

[57] Douds Jr., D.D., Galvez, L., Franke-Snyder, M., Reider, C. and Drinkwater, L.E. (1997) Effect of Compost Addition and Crop Rotation Point upon VAM Fungi. Agriculture, Ecosystems \& Environment, 65, 257-266. http://dx.doi.org/10.1016/S0167-8809(97)00075-3

[58] Pasolon, Y.B., Hirata, H. and Barrow, N.J. (1993) Effect of White Clover (Trifolium repens L.) Intercropping on Growth and Nutrient Uptake of Upland Rice (Oryza sativa L.) in Relation to VA-Mycorrhizae and Soil Fertility. Developments in Plant and Soil Sciences, 54, 331-334.

[59] Jordan, N.R., Zhang, J. and Huerd, S. (2000) Arbuscular-Mycorrhizal Fungi, Potential Roles in Weed Management. Weed Research, 40, 397-410. http://dx.doi.org/10.1046/j.1365-3180.2000.00207.x

[60] Johnson, N.C. (1993) Can Fertilisation of Soil Select Less Mutualistic Mycorrhizae? Ecological Applications, 3, 749757. http://dx.doi.org/10.2307/1942106

[61] Grzyb, Z.S., Piotrowski, W., Sas Paszt, L. and Bielicki, P. (2013) Influence of the Granular Formulation of Florovit on the Quality of Apple and Sour Cherry Maidens in the Organic Nursery-Preliminary Results. Journal of Research and Application in Agricultural Engineering, 58, 193-197.

[62] Sivasankari, S., Venkatesalu, V., Anatharaj, M. and Chandrasekaran, M. (2006) Effect of Seaweed Extract on the Growth and Biochemical Constitutes of Vigna sinensis. Bioresource Technology, 97, 1745-1751. http://dx.doi.org/10.1016/j.biortech.2005.06.016

[63] Malusà, E., Sas Paszt, L., Popińska, W. and Żurawicz, E. (2007) The Effect of a Substrate Containing Arbuscular My- 
corrhizal Fungi and Rhizosphere Microorganisms (Trichoderma, Bacillus, Pseudomonas and Streptomyces) and Foliar Fertilization on Growth Response and Rhizosphere $\mathrm{pH}$ of Three Strawberry Cultivars. International Journal of Fruit Science, 6, 25-41. http://dx.doi.org/10.1300/J492v06n04_04

[64] Cerdán, M., Sánchez-Sánchez, A., Jordá, J.D., Juárez, M. and Sánchez-Andreu, J. (2013) Effect of Commercial Amino Acids on Iron Nutrition of Tomato Plants Grown under Lime-Induced Iron Deficiency. Journal of Plant Nutrition and Soil Science, 176, 859-866. http://dx.doi.org/10.1002/jpln.201200525

[65] Norman, J.R., Atkinson, D. and Hooker, J.E. (1996) Arbuscular Mycorrhizal Fungal-Induced Alteration to Root Architecture in Strawberry and Induced Resistance to the Root Pathogen Phytophthora fragariae. Plant and Soil, 185, 191-198. http://dx.doi.org/10.1007/BF02257524

[66] Malusá, E., Sas-Paszt, L., Jadczuk-Tobjasz, E., Juszczuk, I., Rychter, A., Ciesielska, J. and Popinska, W. (2010) The Effect of Organic Fertilizers and Amendments on Photosynthesis and N Metabolism in Strawberry. 28th International Horticultural Congress, Lisbon, 22-27 August 2010, 637.

[67] Douds, D.D., Janke, R.R. and Peters, S.E. (1993) VAM Fungus Spore Populations and Colonization of Roots of Maize and Soybean under Conventional and Low-Input Sustainable Agriculture. Agriculture, Ecosystems \& Environment, 43, 325-335. http://dx.doi.org/10.1016/0167-8809(93)90095-7

[68] Franke-Snyder, M., Douds Jr., D.D., Galvez, L., Phillips, J.G., Wagoner, P., Drinkwater, L. and Morton, J.B. (2001) Diversity of Communities of Arbuscular Mycorrhizal (AM) Fungi Present in Conventional versus Low-Input Agricultural Sites in Eastern Pennsylvania, USA. Applied Soil Ecology, 16, 35-48. http://dx.doi.org/10.1016/S0929-1393(00)00100-1

[69] Kurle, J.E. and Pfleger, F.L. (1994) Arbuscular Mycorrhizal Fungus Spore Populations Respond to Conversions between Low-Input and Conventional Management Practices in a Corn-Soybean Rotation. Agronomy Journal, 86, $467-$ 475. http://dx.doi.org/10.2134/agronj1994.00021962008600030002x

[70] Sjoberg, J., Persson, P., Martensson, A., Mattsson, L., Adholeya, A. and Alstrom, S. (2004) Occurrence of Glomeromycota Spores and some Arbuscular Mycorrhiza Fungal Species in Arable Fields in Sweden. Acta Agriculturae Scandinavica, Section B-Soil \& Plant Science, 54, 202-212. http://dx.doi.org/10.1080/09064710410030294

[71] Sumorok, B., Sas Paszt, L., Głuszek, S., Derkowska, E. and Żurawicz, E. (2011) The Effect of Mycorrhization and Mulching of Apple Trees "Gold Milenium" and Blackcurrant Bushes "Tiben" on the Occurrence of Arbuscular Mycorrhizal Fungi. Journal of Fruit and Ornamental Plant Research, 19, 35-49.

[72] Purin, S., Filho, K.O. and Stürmer, S.L. (2006) Mycorrhizae Activity and Diversity in Conventional and Organic Apple Orchards from Brazil. Soil Biology \& Biochemistry, 38, 1831-1839. http://dx.doi.org/10.1016/j.soilbio.2005.12.008

[73] Ellis, J.R., Roder, W. and Mason, S.C. (1992) Grain Sorghum-Soybean Rotation and Fertilization Influence on Vesicular-Arbuscular Mycorrhizal Fungi. Soil Science Society of America Journal, 56, 783-794. http://dx.doi.org/10.2136/sssaj1992.03615995005600030019x

[74] Blaszkowski, J. (1993) Comparative Studies of the Occurrence of Arbuscular Fungi and Mycorrhizae (Glomales) in Cultivated and Uncultivated Soils of Poland. Acta Mycologica, 28, 93-140. http://dx.doi.org/10.5586/am.1993.013 
Scientific Research Publishing (SCIRP) is one of the largest Open Access journal publishers. It is currently publishing more than 200 open access, online, peer-reviewed journals covering a wide range of academic disciplines. SCIRP serves the worldwide academic communities and contributes to the progress and application of science with its publication.

Other selected journals from SCIRP are listed as below. Submit your manuscript to us via either submit@scirp.org or Online Submission Portal.
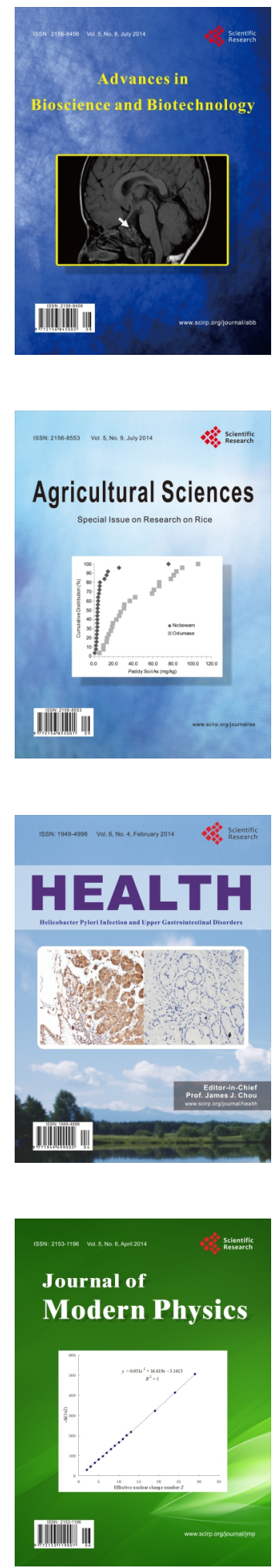
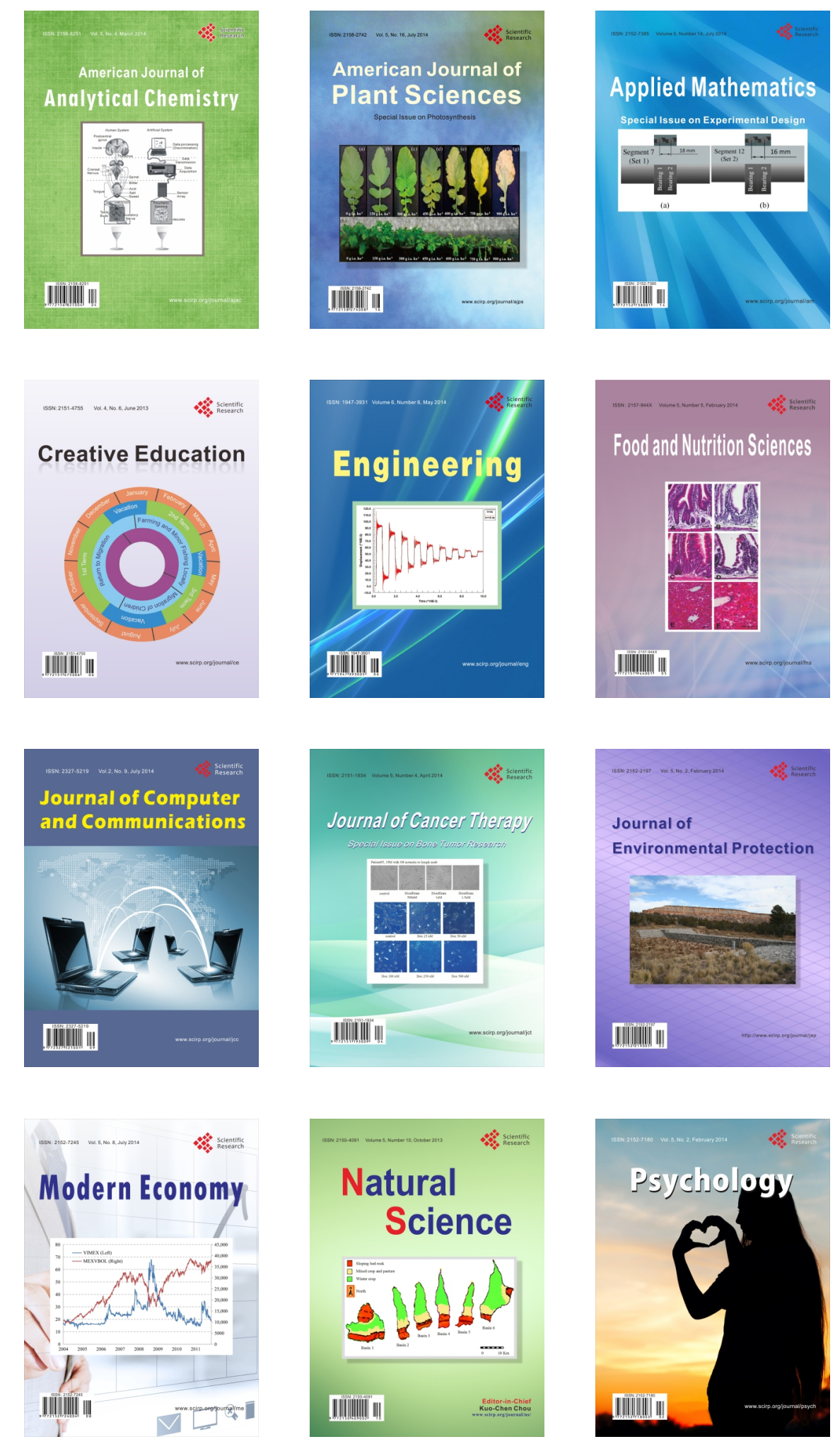